\title{
Edge effect on the spatial distribution of trees in an Araucaria Rainforest fragment in Brazil
}

\author{
Ângela Maria Klein Hentz ${ }^{1,2}$, Ana Paula Dalla Corte ${ }^{1}$, Carlos Roberto Sanquetta ${ }^{1} \&$ Christopher Thomas Blum $^{1}$
}

\begin{abstract}
The objective of this research was to evaluate which species in the Brazilian Araucaria forest have its spatial distribution influenced by edge effects. We performed annual forest inventories inside two one-hectare plots, divided in 10 rectangular subplots, delimited by every 10 meters of edge distance. Each tree with at least $10 \mathrm{~cm}$ at DBH was identified to species level, and their allometric measurements and geographical coordinates were recorded considering the categories living, recruitment and mortality. We analyzed the correlation between the abundance of each species in each subplot and its distance by the Spearman's Correlation Coefficient and a Generalized Additive Model (GAM) with a Poisson distribution. We analyzed the distribution of some species and the ecological groups using a Kernel density model. We observed numerous pioneers and early secondary species with relationship with the edge distance, usually concentrated close to the edges. The late secondary/ climax species are more evenly distributed in the plots, despite of some species, as Eugenia uniflora, are negatively affected by the edge. From these results, it is observed that some light demanding species can be favored to live close to the edges, even if some shadow tolerant species can inhabit this region as well.

Key words: Atlantic forest, ecological groups, forest fragmentation.

Resumo

Neste trabalho objetivou-se avaliar quais espécies florestais apresentam sua distribuição espacial influenciada pelo efeito de borda. Inventários florestais anuais foram realizados em duas parcelas permanentes de 1 hectare cada, divididas em 10 subparcelas retangulares, delimitadas a cada 10 metros de distância da borda. Todos os indivíduos com DAP superior à $10 \mathrm{~cm}$ dentro das parcelas foram identificados ao nível de espécie, e para cada indivíduo foram coletadas suas variáveis alométricas e coordenadas geográficas, considerando as categorias vivos, recrutamento e mortalidade. Analisou-se a correlação entre a abundância de cada espécie em cada subparcela, e a distância da subparcela até a borda, pelo Coeficiente de Correlação de Spearman's e por um modelo aditivo generalizado (GAM) com base na distribuição de Poisson. A distribuição de algumas espécies e dos grupos ecológicos foram analisadas pelo modelo de densidade de Kernel. Foi observado um grande número de espécies pioneiras e secundárias iniciais com relação com a distância da borda, geralmente concentradas próximas à borda. As espécies secundárias tardias ou clímax foram observadas melhor distribuídas dentro das parcelas, apesar de que algumas espécies, como Eugenia uniflora foram negativamente afetadas pela presença da borda. A partir desses resultados observa-se que espécies de hábito heliófilo podem ser favorecidas por terem a habilidade de habitar áreas próximas à borda, apesar de que algumas espécies tolerantes à sombra possam também habitar essa região. Palavras-chave: Mata Atlântica, grupos ecológicos, fragmentação florestal.
\end{abstract}

\section{Introduction}

Forest fragmentation is a process resulted mostly by human intervention, and it causes many environmental problems. This happens because the affected species do not have enough time to respond to the changes with adaptations. The low number of remaining individuals in forest fragments leads to loss of genetic diversity because of the limitation of gene flow by pollen and seed dispersion between fragments (Martins et al. 2008).

The negative effects of fragmentation on the biodiversity are many, and they have

\footnotetext{
${ }^{1}$ Universidade Federal do Paraná, Centro de Ciências Florestais e da Madeira, Av. Prefeito Lothário Meissner 900, Jardim Botânico, 80210-170, Curitiba, PR, Brasil.

${ }^{2}$ Author for correspondence: angelakhentz@gmail.com
} 
distinct magnitudes according to a number of variables. Considering a broader view on these effects, it's possible notice area reduction and isolation (Geneletti 2004), direct mortality of many individuals (Lang \& Blaschke 2009), disturbances on hydrological cycles (Scariot et al. 2005; Laurance et al. 2011), increase of fire risk (Laurance \& Williamson 2001; Cochrane \& Laurance 2002), introduction of invasive plants (Laurance et al. 2009), and others. In a review of these effects, Fahrig (2003) observed that the forest fragmentation effects are mostly related to the habitat loss rather than to the fragmentation itself, but also that there are two major negative effects caused by the fragmentation: the area reduction and the edge effect.

The edge effect can be characterized by a large number of changes in biotic and abiotic factors (Murcia 1995), and occurs by the existence of an abrupt contact between the forest and the surrounding matrix (Laurance et al. 1998a). In small fragments or fragments with irregular shape the edge effect is stronger (Scariot et al. 2003), because of the bigger proportion of affected area in relation to protected area. The edge effect is biologically presented by the presence of a distinct plant community on the edge, in relation to the plants found in the interior (Rodrigues \& Nascimento 2006).

Some authors have stated that this effect begins soon after the fragmentation of the original forest, and the first event to happen is a higher mortality of trees (Matlack 1994), mainly due to the increased incidence of wind and water stress caused by higher insolation (Laurance et al. 1998b). Subsequently, a high rate of recruitment starts, creating an area with greater richness and abundance of species (Harper et al. 2005), mainly by typical species from areas without forest cover, like pioneers and lianas (Murcia 1995). It is noticeable that with the favoring of light-demanding species, characteristic of the early stages of forest succession, competition with the shade tolerant species of more advanced successional stages occurs, which can result in changes in natural characteristics of the habitat (Scariot et al. 2003). Harper et al. (2005) characterize the edge effect in two categories, primary and secondary effects, and they observed that the secondary responses can have a longer effect than the primary responses, as well as have a highest magnitude, and one of these responses is the changes in species composition.
It is also necessary to consider that when an edge effect is present, there is a microclimatic gradient where wind speed is increased and humidity is reduced. These microclimate conditions at the edge can reach considerable distances into the forest interior, reducing the amount of area where the original microclimatic conditions are still available (Ribeiro \& Marques 2005). The distance inside the forest that those microclimatic changes can reach depends on the variable in question (Laurance et al. 2002), so the response in the vegetation also is variable for each species, according to the conditions of the new habitat created.

The distance of edge effect cannot be generalized, since this factor is different for each variable response considered, ranging from zero to more than $400 \mathrm{~m}$ into the forest (Laurance et al. 2002). Also, each ecosystem has a distinct response according to the forest type (Orihuela et al. 2015), surrounding matrix (Harper et al. 2005) and edge age (Laurance et al. 2011). In Araucaria Rainforest region Fontoura et al. (2006) observed approximately $50 \mathrm{~m}$ of edge impact on wood species, and noticed that a great number of species are just found close to the edge, while some other species are not found until some minimum distance from the edge. Because of these facts, it's possible infer that the response of the edge effect is distinct for each species.

Despite the existence of several studies investigating edge effects on the structure of many forest types, analysis of the effect of the edge on each species within the forest is difficult to measure, mainly because of the high cost to measure allometric variables and assign geographical position for each individual tree (De Cesaro et al. 1994). Also, the conventional GPS does not have an adequate precision to measure the position of trees, and this precision is lower in areas with closed coverage, as is the case of forests, because of the insufficient reception in these areas (Pirti et al. 2010). Therefore, the possibility of making a complete analysis in a forest fragment is an opportunity of great interest.

The Araucaria Rainforest is an ecosystem that belongs to the Atlantic Forest Phytogeographical Domain, one of the 25 hotspots of diversity on the planet (Galindo-Leal \& Câmara 2005). This ecosystem is characterized by the predominant presence of Araucaria angustifolia (Bertol.) Kuntze, also known as Brazilian Pine. The Araucaria Rainforest has been intensively 
deforested, remaining currently at only $10 \%$ of the original coverage area (Galindo-Leal \& Câmara 2005).

Considering the massive deforestation of the Araucaria Rainforest, this ecosystem has been impacted by the effects of forest fragmentation and edge effect and presents a large number of species in danger of extinction (Medeiros et al. 2005). Because of that, it is important to study the impacts of the forest fragmentation to create plans to maintain the remaining biodiversity. There have been a number of studies carried out in the Araucaria Rainforest about the edge effect on forests, relatives to edge effect on vascular epiphytes (Bianchi \& Keresten 2014), changes in plant diversity and phytosociology along the edge distance (Fontoura et al. 2006; Ferreira et al. 2016; Orihuela et al. 2015), seed predation (Baldissera \& Ganade 2005) and changes in forest structure (Malchow et al. 2006).

Considering this information, the objective of this study was to evaluate which species have their spatial distribution influenced by the edge effect, in two one-hectare plots located in an Araucaria Rainforest fragment. We tested the hypotheses that some species have a higher number of individuals close to the edge, while others have more individuals far from the edge. We also tested the hypothesis that the pioneers and early secondary species are located closest to the edges, while climax and late secondary species are mostly concentrated in the interiors.

\section{Material and Methods}

\section{Study area}

In this study, we used two permanent onehectare plots from the Experimental Station of Federal University of Paraná, with coordinates $25^{\circ} 34^{\prime} 18^{\prime \prime} \mathrm{S}$ and $50^{\circ} 5^{\prime} 56^{\prime \prime} \mathrm{W}$, in the municipality of São João do Triunfo, Paraná state - Brazil (Fig. 1).

The experimental station has a total area of approximately $33 \mathrm{ha}$, which is divided into 30 plots. Four of these plots have been measured annually since 1995 by the Brazilian Long Term Ecological Research Program (PELD) Site 9.

The study area has an altitude of $780 \mathrm{~m}$, and is covered by an Araucaria Rainforest fragment. According to historical data, the experimental station area suffered selective logging, at least 40 years before, and can be considered a community in an advanced stage of succession (Schaaf et al. 2006).

The regional climate is $\mathrm{Cfb}$, according to Köppen classification, temperate always moist, with annual average temperature between 17 and $18{ }^{\circ} \mathrm{C}$. Concerning to the soil, the study area is characterized by an association of Red-Yellow Argisols, Tb Haplic Cambisols and Red Latosols, all of them dystrophic (Durigan 1999).

From the four plots measured each year, we used two in this study, which we called Pine and Agriculture. These two plots were chosen because both have direct contact with the external edge, while the other two are located completely inside the forest. Both plots have the shape of a square with $100 \mathrm{~m}$ on each side, and cover 1 ha each. The Agriculture plot is bordered on the southeast side by agriculture (there is a small firebreak between the forest and the agriculture), and the Pine plot is bordered on the northwestern side by a country road and further by a commercial Pinus sp. stand.

In the Pine plot the predominant species is Araucaria angustifolia, and there are reports that in the past (1982) this area was hit by a forest fire (Schaaf et al. 2006). The Agriculture plot is dominated by large hardwood trees like Ocotea porosa (Nees \& Mart.) Barroso.

The complete phytosociology analysis of the plots is not presented in this paper, but this data is available in other studies, as Barreto (2015) and Dalla Lana (2013).

\section{Data collection and processing}

For this study we used data of trees found in the two plots located on the edge of the vegetation fragment. These data were collected in annual inventories conducted during the period 1995 to 2013. The inventories considered only trees with diameter at breast height (DBH $-1.3 \mathrm{~m}$ ) equal or above $10 \mathrm{~cm}$. Since the first inventory, the trees were marked using metal plates with a number on each, so in the consecutive inventories, the trees are identified by the number. Every year, the living trees are measured, and the new trees that reached the minimum $\mathrm{DBH}$ value were included as recruitment, receiving a number. If some tree marked with a number was found dead, we reported this information as well.

Since the first year of measurement and in the years following, a sketch of the spatial arrangement of all trees measured in the plot was created, so that it was possible to spatially locate all measured individuals during that period. The process was done by collecting the coordinates of each plot (plots with $100 \times 100 \mathrm{~m}$ ) using a precision GPS. After that, we used the coordinates of one plot's vertex and measured the distance of each tree to this point 


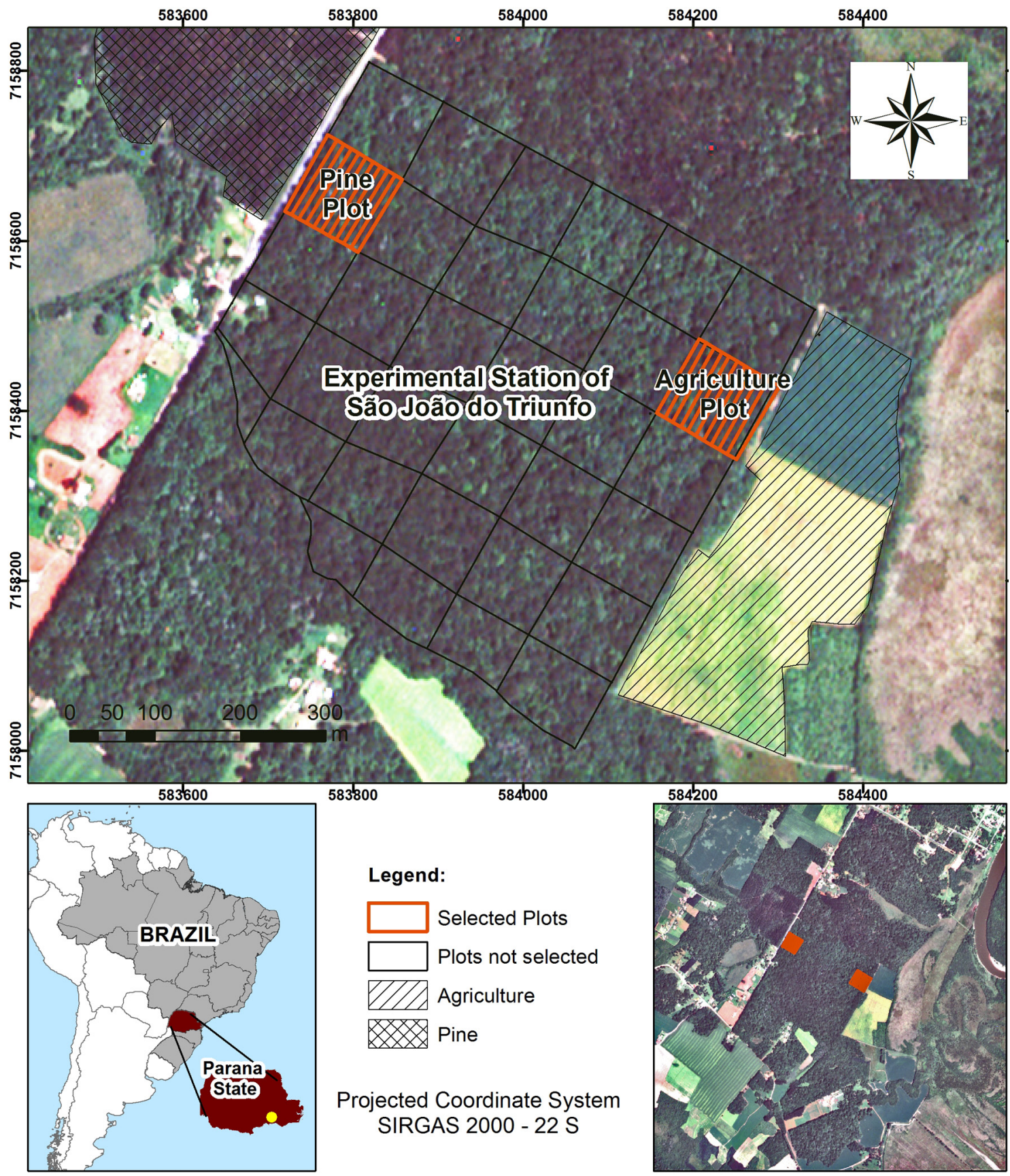

Figure 1 - Localization of the Experimental Station of São João do Triunfo, and the delimitation of the studied plots.

with a measuring tape. The position was drawn on a graph paper, and later the coordinates of each tree were imported in a GIS system.

The plots were divided into subplots of $10 \times$ $100 \mathrm{~m}$, arranged in a gradient of increasing distance from the edge (Fig. 2), and then all inventoried trees were plotted inside those two plots. In the subplots, the position of each tree was plotted, analyzed in the following categories: a) Living individuals: all trees measured in 2013, including the remaining of the trees found in 1995 and the recruited trees measured in the subsequent inventories; $b$ ) Recruitment individuals: all individuals that were not measured in 1995, but that reached the minimum DBH in the subsequent years, also including the recruited individuals that died during this period; 


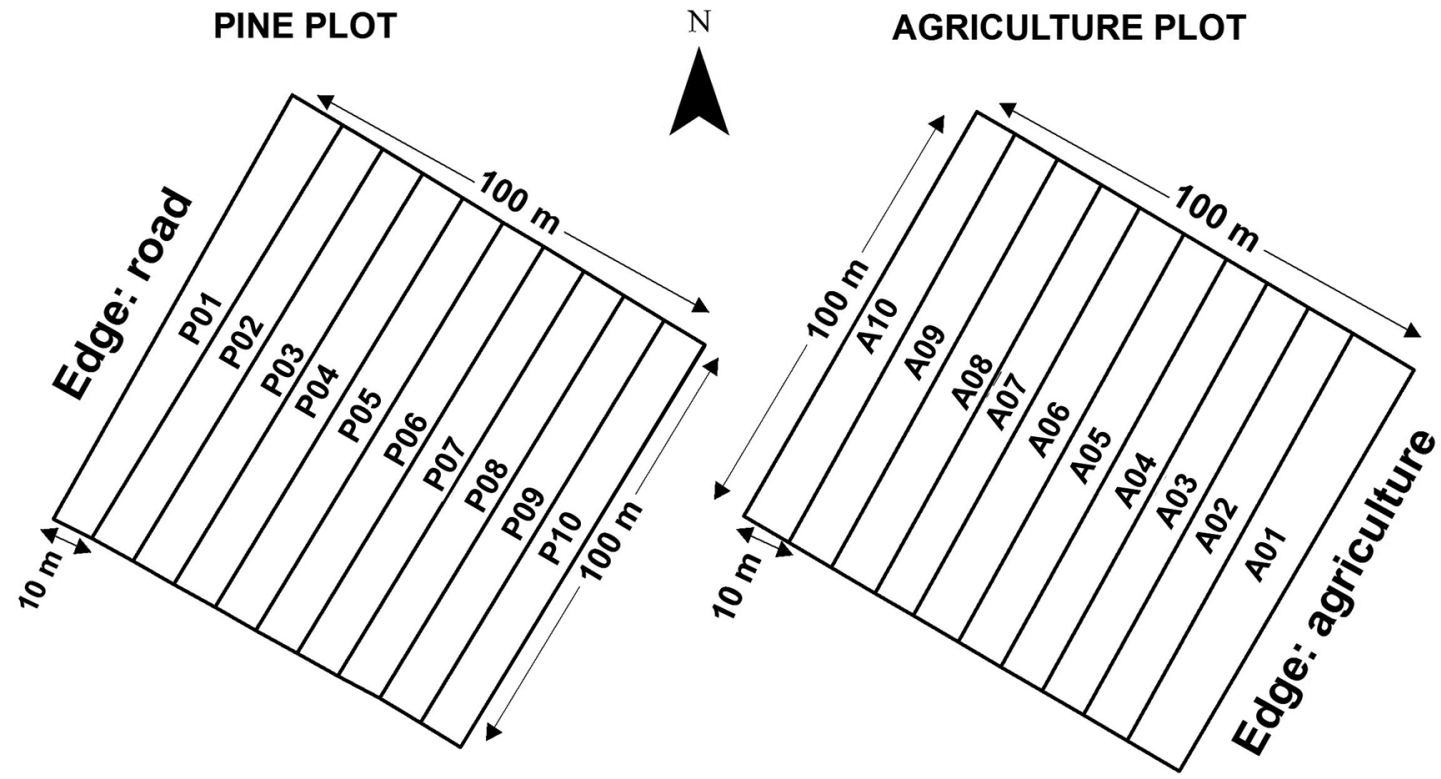

Figure 2 - Division of the plots according to the edge distance.

and c) Mortality individuals: all individuals that were measured in any year, but later were found dead, including also the dead individuals found in the first inventory.

As some species were represented just by a few individuals, it was decided to consider only the species with 10 or more individuals for living and recruitment, and 5 or more individuals in the mortality group, in order to avoid false tendencies. Some species are found in both plots, Pine and Agriculture, but we processed the data for each plot separately, since there are differences in the vegetation and edge characteristics between them. This means that when a species had at least 10 individuals in one plot but not in the other, only one plot was analyzed.

With this data, it was possible to evaluate the correlation between the number of individuals of each species in relation to the edge distance. This was done considering the number of individuals of each species in each subplot (the abundance), and the distance of each subplot from the edge. For this we calculated the Spearman's correlation coefficient $(\rho)$, characterized as a nonparametric (distribution-free) rank statistic, that was proposed as a measure of the strength of the association between two variables (Hauke and Kossowski 2011). The correlation was calculated using the software R (R Core Team 2017) and the package pspearman (Savicky 2014). The correlation's significance was tested by the p-value, and we considered as significant the correlations with p-value smaller than 0.05 (confidence level of $95 \%$ ).

We also used a Generalized Additive Model (GAM) to evaluate the relationship between the number of individuals and the edge distance. The GAM model fits a smoothing curve that characterizes the non-linear relationships between the variables (Zuur et al. 2009). In this case, we used a Poisson distribution, usually applied to count data (Zurr et al. 2009). We used the package mgcv (Wood 2011) for R (R Core Team 2017). Since our interest was mostly in identifying the distance influence, we did evaluate the significance of the explanatory variable (distance smoothed) in the models by considering the p-value. We considered the smoothed distance as significant if the p-value was smaller than 0.05 . The values of the Spearman's correlation coefficient and GAM model, as well the p-values for each, are not presented in this paper but are available in the complementary data section.

After the evaluation of the significance of the smoothed distance in the GAM model, we selected some species with a significant correlation with the edge distance, and we applied the occurrence of the individuals in a Kernel density model to evaluate the range of distribution of every species in the area. The Kernel model was calculated using ArcMap 10.4.1, and is based on Silverman (1986). Because of the large number of species, we presented in this paper only a limited number. For the selection, we chose 
the species with p-values considered significant at the level of 0.001 for the smoothed distance. The distribution and Kernel density model for the other species are presented in the complementary data section.

In order to complement the assessment of spatial distribution, the recorded species were classified according to their ecological group, based in the characteristics proposed by Leitão Filho (1993) adapted by Santos et al. (2004). This classification was based in 3 groups: Pioneer (P), Early Secondary (ES), and Late Secondary or Climax (LS/C). The classification was based on comparison between the description of each class done by Santos et al.

Table 1 - Species found in the plots (Pine and Agriculture), and their respective ecological group and botanic family.

\begin{tabular}{|c|c|c|}
\hline Species & EG & Family \\
\hline Clethra scabra Pers. & $\mathrm{P}$ & Clethraceae \\
\hline Mimosa scabrella Benth. & $\mathrm{P}$ & Fabaceae \\
\hline Moquiniastrum polymorphum (Less.) G. Sancho & $\mathrm{P}$ & Asteraceae \\
\hline Myrsine coriacea (Sw.) R.Br. ex Roem. \& Schult. & $\mathrm{P}$ & Primulaceae \\
\hline Cedrela fissilis Vell. & ES & Meliaceae \\
\hline Lithrea brasiliensis Marchand & ES & Anacardiaceae \\
\hline Ilex brevicuspis Reissek & $\mathrm{LS} / \mathrm{C}$ & Aquifoliaceae \\
\hline Ilex theezans Mart. ex Reissek & $\mathrm{LS} / \mathrm{C}$ & Aquifoliaceae \\
\hline Araucaria angustifolia (Bertol.) Kuntze & $\mathrm{LS} / \mathrm{C}$ & Araucariaceae \\
\hline Syagrus romanzoffiana (Cham.) Glassman & $\mathrm{LS} / \mathrm{C}$ & Arecaceae \\
\hline Cinnamodendron dinisii Schwacke & $\mathrm{LS} / \mathrm{C}$ & Canellaceae \\
\hline Sloanea lasiocoma K. Schum. & $\mathrm{LS} / \mathrm{C}$ & Elaeocarpaceae \\
\hline Sapium glandulosum (L.) Morong & ES & Euphorbiaceae \\
\hline Cinnamomum amoenum (Nees \& Mart.) Kosterm. & ES & Lauraceae \\
\hline Cinnamomum sellowianum (Nees \& Mart.) Kosterm. & ES & Lauraceae \\
\hline Ocotea puberula (Rich.) Nees & ES & Lauraceae \\
\hline Nectandra grandiflora Ness & $\mathrm{LS} / \mathrm{C}$ & Lauraceae \\
\hline Nectandra lanceolata Nees & $\mathrm{LS} / \mathrm{C}$ & Lauraceae \\
\hline Nectandra sp. & $\mathrm{LS} / \mathrm{C}$ & Lauraceae \\
\hline Ocotea porosa (Nees \& Mart.) Barroso & $\mathrm{LS} / \mathrm{C}$ & Lauraceae \\
\hline Luehea divaricata Mart. & ES & Malvaceae \\
\hline Myrcia splendens (Sw.) DC. & ES & Myrtaceae \\
\hline Blepharocalyx salicifolius (Kunth) O. Berg & $\mathrm{LS} / \mathrm{C}$ & Myrtaceae \\
\hline Campomanesia xanthocarpa (Mart.) O.Berg & $\mathrm{LS} / \mathrm{C}$ & Myrtaceae \\
\hline Eugenia handroana D. Legrand & $\mathrm{LS} / \mathrm{C}$ & Myrtaceae \\
\hline Eugenia uniflora L. & $\mathrm{LS} / \mathrm{C}$ & Myrtaceae \\
\hline Myrceugenia euosma (O. Berg) D. Legrand & $\mathrm{LS} / \mathrm{C}$ & Myrtaceae \\
\hline Prunus brasiliensis (Cham. \& Schltdl.) D. Dietr. & ES & Rosaceae \\
\hline Casearia decandra Jacq. & $\mathrm{LS} / \mathrm{C}$ & Salicaceae \\
\hline Allophylus edulis (A.St.-Hil. et al.) Hieron. ex Niederl. & $\mathrm{LS} / \mathrm{C}$ & Sapindaceae \\
\hline Cupania vernalis Cambess. & $\mathrm{LS} / \mathrm{C}$ & Sapindaceae \\
\hline Matayba elaeagnoides Radlk. & $\mathrm{LS} / \mathrm{C}$ & Sapindaceae \\
\hline Styrax leprosus Hook. \& Arn & ES & Styracaceae \\
\hline
\end{tabular}

$(\mathrm{EG}=$ Ecological Group; $\mathrm{P}=$ Pioneer; $\mathrm{ES}=$ Early Secondary; LS/C = Late Secondary or Climax $)$ 
(2004) and each species characteristic. The species and their ecological group are presented in Table 1. We also applied the Kernel density model on the ecological group distribution, considering the total number of individuals for ecological group considering the groups of Pioneers and Early Secondary as one in this analysis. More information about ecological group distribution and edge effect of this plots can be found in Hentz (2015).

\section{Results}

In the Pine plot 765 live individuals with $\mathrm{DBH} \geq 10 \mathrm{~cm}$ belonging to 49 species were sampled in 2013, among which, 16 species had an abundance of 10 or more individuals, totaling 655 individuals. Only these species were analyzed for their correlation with the edge distance (Tab. 2). According to the Spearman's correlation coefficient, the species Cinnamomum amoenum, Cinnamomum sellowianum, Clethra scabra and Moquiniastrum polymorphum have a significant $(p<0.03)$ correlation with the edge distance, and this correlation was negative in all cases, so they are mostly found close to the edge. On the other hand, the GAM model showed that the species Cinnamomum amoenum, Clethra scabra, Eugenia handroana, Matayba elaeagnoides, Moquiniastrum polymorphum, Myrceugenia euosma, Myrsine coriacea and Nectandra grandiflora have a significant $(\mathrm{p}<0.04)$ relationship with the distance from the edge.

Concerning to the recruitment trees in the studied period, 345 individuals and 42 species were observed in the Pine plot, of which only 8 species had more than 10 individuals, totaling 227 individuals considered in this study. According to the Spearman's correlation coefficient, a similar group of species with a significant correlation with the edge distance found in the living group was also observed in the recruitment. These species are Cinnamomum amoenum, Cinnamomum sellowianum, Clethra scabra, Myrsine coriacea and Nectandra grandiflora $(\mathrm{p}<0.03)$ and again the correlations were negative, so these species were found regenerating nearer to the edge. Considering the GAM model, the species with a significant $(\mathrm{p}<0.01)$ relationship with the distance are Cinnamomum amoenum, Matayba elaeagnoides, Myrsine coriacea and Nectandra grandiflora.

We observed 185 dead individuals for 27 species in Pine plot, from which 11 had a minimum of 5 individuals (totaling 152 individuals). From the mortality group, only Araucaria angustifolia and
Matayba elaeagnoides are considered significant ( $p$ $<0.02$ ) by the Spearman's correlation coefficient when correlated with the edge distance, and they have a positive relationship (more dead individuals in the interior). The GAM model showed a distinct result since the model considered that the species Mimosa scabrella, Myrsine coriacea and Nectandra grandiflora have a significant $(\mathrm{p}<0.05)$ relationship with the edge distance.

The Kernel density model results for the Pine plot are presented in Figure 3; as well, the representation of the individuals is observed in the inventories. The species Cinnamomum amoenum and Myrsine coriacea present a similar trend for living and recruitment with a large number and density of individuals close to the edges, but a small number of individuals are closer to the interior. In both cases, the interior individuals don't have as high a density as those at the edges. It is interesting to notice that for Cinnamomum amoenum the individuals in the interior are recently recruited, while for Myrsine coriacea the opposite happens, since the recruitment has only one individual close to the interior.

Clethra scabra also presented majority of individuals in the first three subplots, but there were a few trees of this species in the plot's interior, including the last subplot, between 90-100 meters from the edge. Moquiniastrum polymorphum is the only one which is concentrated in the first 4 subplots, up to 40 meters away from the border, presenting the largest number of individuals in the first subplot. Besides that, the species Moquiniastrum polymorphum and Clethra scabra don't present a large density of individuals in any region of the plot.

In the Agriculture plot, 52 species and 622 individuals of living trees (Tab. 2) were observed in 2013, similar to the number found in the Pine plot. Of these species, 18 had a minimum of 10 individuals, in a total of 467 individuals. Considering the Spearman's correlation coefficient, the species Araucaria angustifolia, Eugenia uniflora, Matayba elaeagnoides and Styrax leprosus have a significant $(\mathrm{p}<0.03)$ correlation with the edge distance. These correlations are negative for Araucaria angustifolia and Styrax leprosus, and positive for Eugenia uniflora and Matayba elaeagnoides. Considering the GAM model, the number of species with a significant $(p<0.03)$ relationship with the edge distance is larger, including the species Araucaria angustifolia, Blepharocalyx salicifolius, Campomanesia xanthocarpa, Cinnamodendron 
Table 2 - Species that presented significant association with edge distance, according to the Spearman's Correlation Coefficient and the Generalized Additive Model in Pine and Agriculture plots.

\begin{tabular}{|c|c|c|c|}
\hline Plot & Category & Spearman's & GAM \\
\hline \multirow{16}{*}{ Pine } & \multirow{8}{*}{ Living } & Cinnamomum amoenum $(\mathrm{N})$ & Cinnamomum amoenum \\
\hline & & Cinnamomum sellowianum (N) & Clethra scabra \\
\hline & & Clethra scabra $(\mathrm{N})$ & Eugenia handroana \\
\hline & & \multirow[t]{5}{*}{ Moquiniastrum polymorphum (N) } & Matayba elaeagnoides \\
\hline & & & Moquiniastrum polymorphum \\
\hline & & & Myrceugenia euosma \\
\hline & & & Myrsine coriacea \\
\hline & & & Nectandra grandiflora \\
\hline & \multirow{5}{*}{ Recruitment } & Cinnamomum amoenum $(\mathrm{N})$ & Cinnamomum amoenum \\
\hline & & Cinnamomum sellowianum $(\mathrm{N})$ & Matayba elaeagnoides \\
\hline & & Clethra scabra $(\mathrm{N})$ & Myrsine coriacea \\
\hline & & Myrsine coriacea $(\mathrm{N})$ & Nectandra grandiflora \\
\hline & & \multicolumn{2}{|l|}{ Nectandra grandiflora $(\mathrm{N})$} \\
\hline & & Araucaria angustifolia $(\mathrm{P})$ & Mimosa scabrella \\
\hline & Mortality & Matayba elaeagnoides $(\mathrm{P})$ & Myrsine coriacea \\
\hline & & & Nectandra grandiflora \\
\hline \multirow{18}{*}{ Agriculture } & \multirow{13}{*}{ Living } & Araucaria angustifolia $(\mathrm{N})$ & Araucaria angustifolia \\
\hline & & Eugenia uniflora $(\mathrm{P})$ & Blepharocalyx salicifolius \\
\hline & & Matayba elaeagnoides $(\mathrm{P})$ & Campomanesia xanthocarpa \\
\hline & & Styrax leprosus $(\mathrm{N})$ & Cinnamodendron dinisii \\
\hline & & & Eugenia uniflora \\
\hline & & & Matayba elaeagnoides \\
\hline & & & Myrcia splendens \\
\hline & & & Nectandra lanceolata \\
\hline & & & Ocotea porosa \\
\hline & & & Ocotea puberula \\
\hline & & & Prunus brasiliensis \\
\hline & & & Sloanea lasiocoma \\
\hline & & & Styrax leprosus \\
\hline & \multirow{2}{*}{ Recruitment } & Eugenia uniflora $(\mathrm{N})$ & Eugenia uniflora \\
\hline & & Styrax leprosus $(\mathrm{N})$ & Styrax leprosus \\
\hline & \multirow{3}{*}{ Mortality } & Styrax leprosus (N) & Casearia decandra \\
\hline & & & Ocotea puberula \\
\hline & & & Styrax leprosus \\
\hline
\end{tabular}

GAM = generalized additive model; $\mathrm{N}=$ negative correlation; $\mathrm{P}=$ positive correlation. 


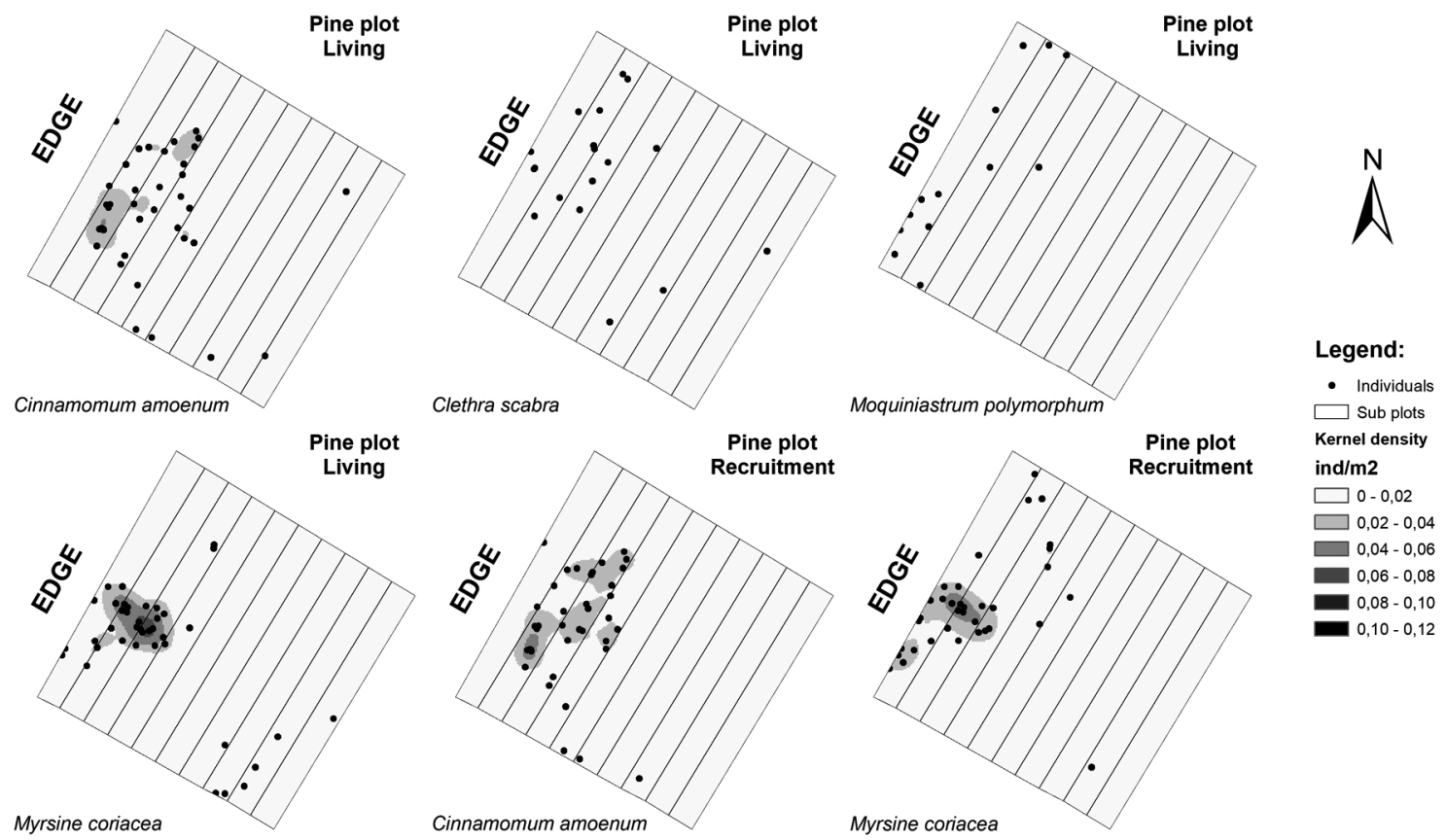

Figure 3 - Spatial distribution and Kernel density of selected species affected by the edge distance in Pine plot.

dinisii, Eugenia uniflora, Matayba elaeagnoides, Myrcia splendens, Nectandra lanceolata, Ocotea porosa, Ocotea puberula, Prunus brasiliensis, Sloanea lasiocoma and Styrax leprosus.

A total of 39 species and 204 individuals were registered as recruitment in the Agriculture plot, of which only four had more than 10 individuals (in a total of 93 individuals). Among these, the species, Eugenia uniflora and Styrax leprosus, presented a significant $(\mathrm{p}<0.03)$ correlation with the edge distance based on the Spearman's correlation coefficient, as well as presented a significant $(\mathrm{p}<$ 0.01 ) relationship according to the GAM model. The correlation was positive for Eugenia uniflora and negative for Styrax leprosus.

A total 36 species and 187 individuals were found dead, of which 11 had a minimum of 5 trees (in a total of 128 individuals). The species Styrax leprosus was the only one with a significant ( $\mathrm{p}$ $<0.03$ ) correlation (negative) between mortality and edge distance considering the Spearman's correlation coefficient. By the GAM model, Casearia decandra, Ocotea puberula and Styrax leprosus have a significant $(\mathrm{p}<0.05)$ relationship with the edge distance.

The Kernel density model of the selected species in the Agriculture plot are shown in Figure 4. Eugenia uniflora is the only species that show a high density of individuals in the interior (mostly in the west corner), even presenting some individuals in all distances, and that is also noticeable in that most the individuals in the middle of the plot or closer to the edge are recruited in the studied period.

Styrax leprosus is the species with the higher density of individuals, and these trees are found mostly in the edges with few individuals in the interior. A similar pattern was observed for Nectandra lanceolata, and in a small scale for Ocotea puberula. Ocotea porosa showed a larger number of individuals in the first subplot after the edge, but also presented individuals in almost all subplots. Because of this distribution in the plot, Ocotea porosa did not present a high density of individuals in any region.

In relation to the ecological groups (EG), the results are presented in Table 3. In the Pine plot, all ecological groups in the three situations (living, recruitment and mortality) presented a significant $(p<0.03)$ correlation with the edge distance by the Spearman's Correlation Coefficient. As well, the distance was considered significant $(\mathrm{p}<$ 0.001) in the GAM model for the three ecological groups. The correlation was positive for the late secondary/climax species only in the living and mortality categories, while in the recruitment this EG presented a negative correlation. This means 


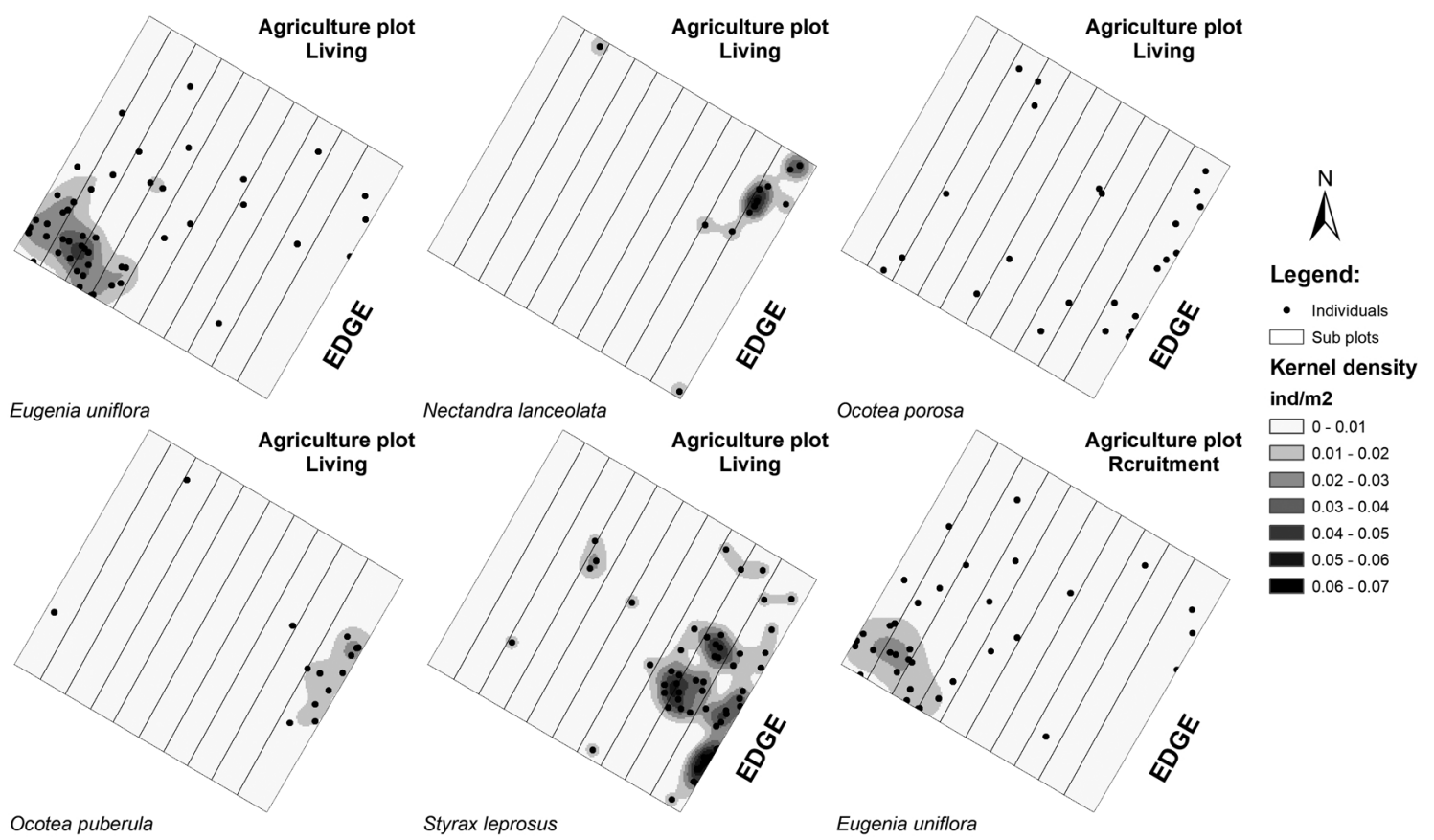

Figure 4 - Spatial distribution and Kernel density of selected species affected by the edge distance in Agriculture plot.

there are more individuals regenerating close to the edge. The pioneer and early secondary groups presented negative correlations in all cases.

In the Agriculture plot, only the living and mortality categories for pioneer and early secondary individuals were considered significantly $(\mathrm{p}<0.02)$ correlated to edge distance, and in both cases, that correlation was negative. On the other hand, considering the GAM model, the only case where the edge distance was not significant $(\mathrm{p}>0.05)$ was for the mortality individuals from the late secondary/climax ecological group.

Table 3 - Ecological groups that presented significant association with edge distance, according to the Spearman's Correlation Coefficient and the Generalized Additive Model in Pine and Agriculture plots.

\begin{tabular}{lll}
\hline Plot & Spearman's & GAM \\
\hline & Living P and ES (N) & Living P and ES \\
& Living LS/C and C (P) & Living LS/C and Climax \\
Pine & Recruitment P and ES (N) & Recruitment P and ES \\
& Recruitment LS/C (N) & Recruitment LS/C \\
& Mortality P and ES (N) & Mortality P and ES \\
& Mortality LS/C (P) & Mortality LS/C \\
\hline & Living P and ES (N) & Living P and ES \\
& Mortality P and ES (N) & Living LS/C and Climax \\
Agriculture & & Recruitment P and ES \\
& & Recruitment LS/C \\
& & Mortality P and ES
\end{tabular}

$\mathrm{GAM}=$ generalized additive model; $\mathrm{P}=$ Pioneer; $\mathrm{ES}=$ Early Secondary LS/C = Late Secondary or Climax; and, in brackets, $\mathrm{N}=$ negative correlation; $\mathrm{P}=$ positive correlation. 


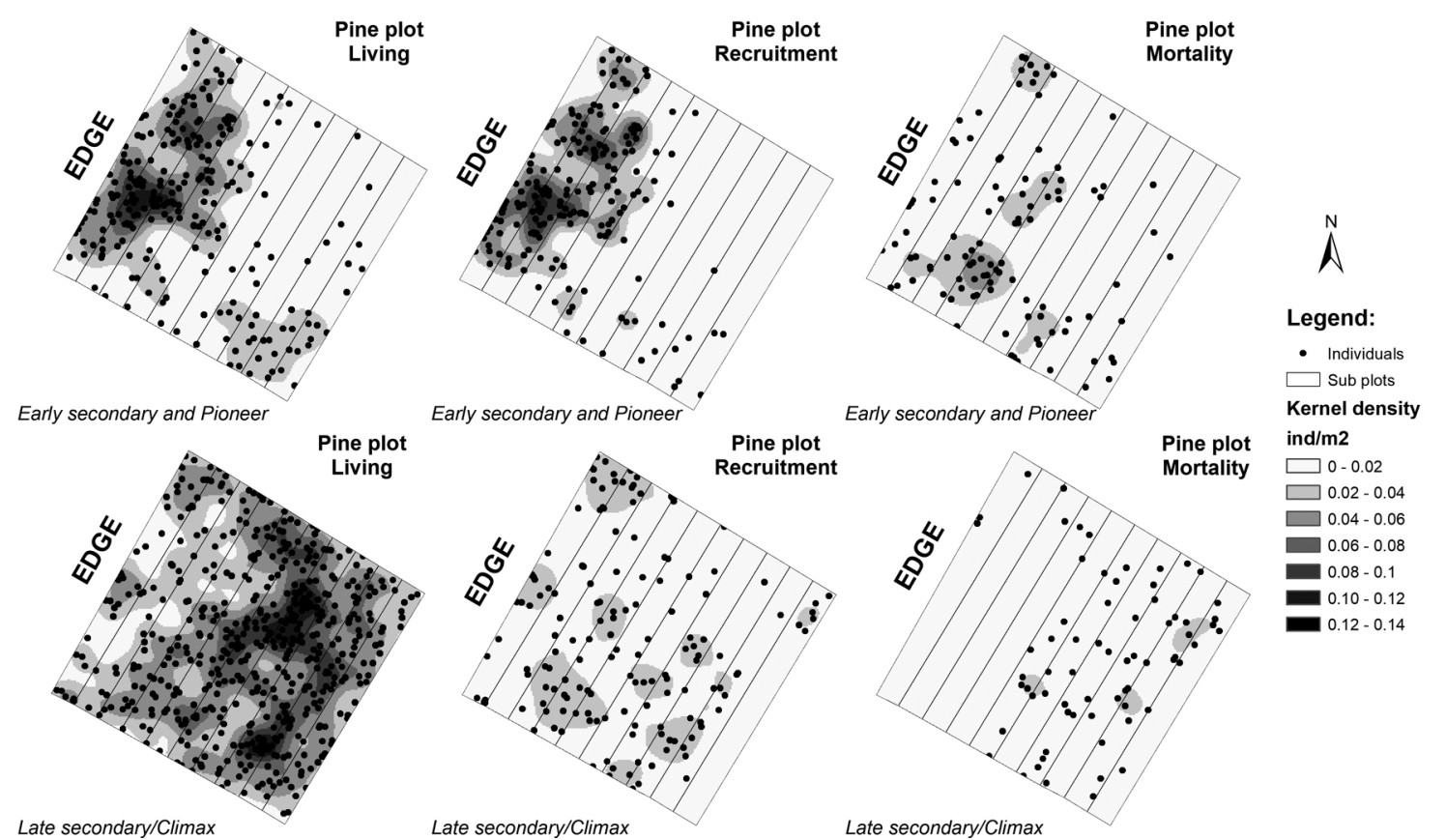

Figure 5 - Spatial distribution and Kernel density of ecological groups in relation to the edge distance in Pine plot.

The results of the Kernel density model of the ecological groups are presented in Figures 5 and 6. We can observe that in the Pine plot the pioneer and early secondary groups have a high density of individuals in the edge for living and recruitment individuals, whereas for mortality, there are some spots of large density in the interior, but in general dead individuals are in all the plot. The late secondary/climax group presented a high density of individuals in almost the entire plot, considering the living individuals,

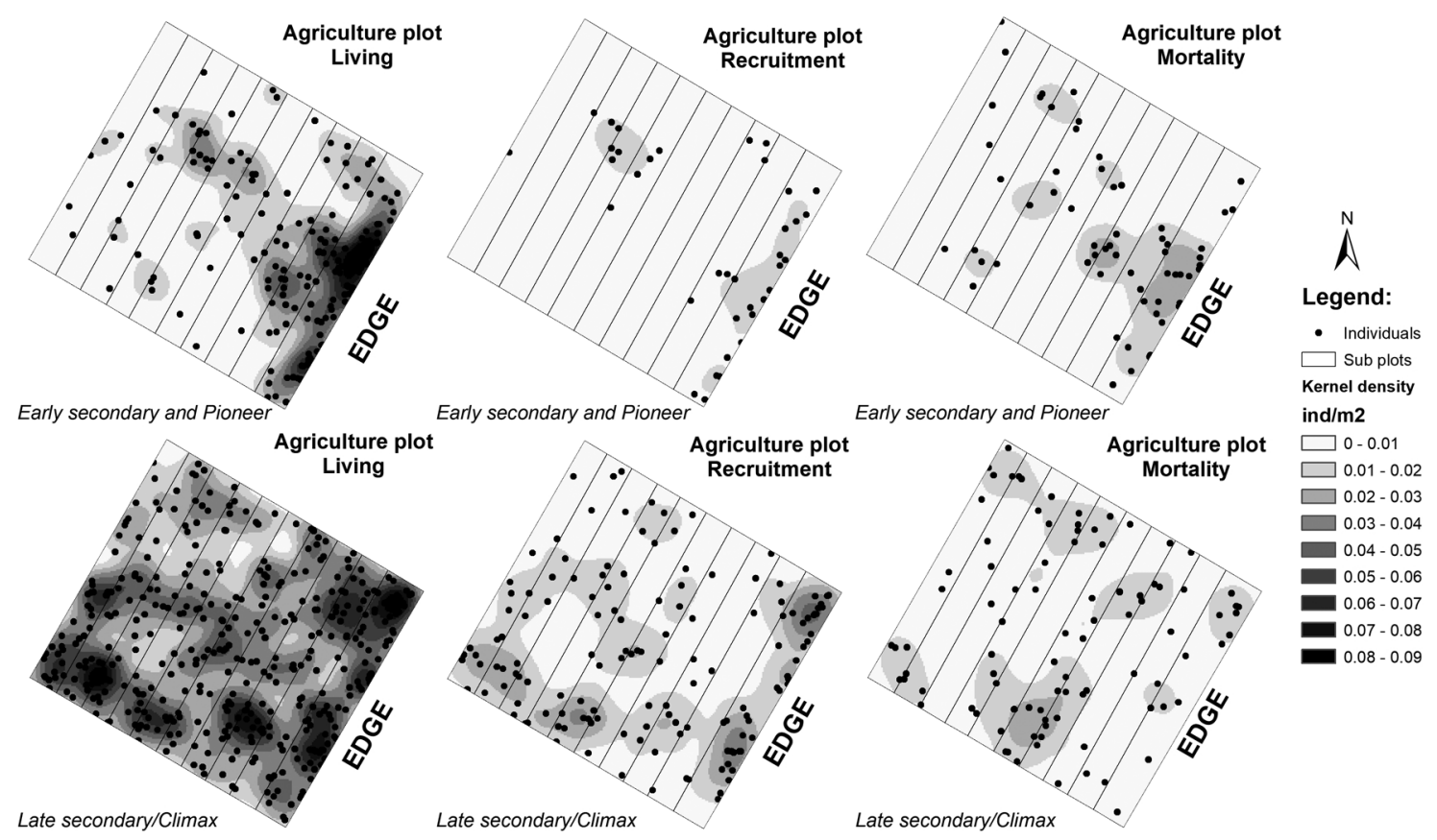

Figure 6-Spatial distribution and Kernel density of ecological groups in relation to the edge distance in Agriculture plot. 
except for the first meter closest to the edge. The recruitment was well distributed, and the mortality was almost nonexistent in the first four plots closest to the edge.

In the Agriculture plot, the pioneer and early secondary groups are concentrated close to the edges for the three categories, but in the living group, the density of individuals is higher. On the other hand, the late secondary/climax group is well distributed in the plot with some spots of high density of individuals in the edge and the west side for living and recruitment categories.

\section{Discussion}

In the Pine plot, the Spearman's correlation coefficient showed a significant relationship almost only for pioneers and early secondary species in the living and recruitment categories, while for the mortality, the correlation significance was observed mostly in the late secondary/climax category. Also, all the significant correlations in living and recruitment categories are negative even for the recruitment of Nectandra grandiflora (considered late secondary/climax). That means that there is a concentration of pioneers and early secondary species regenerating and living closer to the edges. That was expected, since pioneer and early secondary species require higher levels of solar radiation for germination and growth; therefore, they grow in forest gaps (Felfili et al. 1999) as well as in edge areas (Murcia 1995). For the mortality, most of the significant correlations are positive with the edge distance, i.e., there are more individuals of this species dying in the interior of the plot than in the edges.

Considering the Kernel density model for the ecological groups, this finding is more visible for both plots. The pioneers and early secondary species are mostly concentrated in the edges with more emphasis in the living and recruitment categories, while the late secondary/ climax group is more homogeneously distributed in the plots, occurring close to the edges. In fact, in the Agriculture plot, there is a higher density of late secondary/climax individuals living and regenerating close to the edges and in the west side of the plot. This pattern doesn't occur in the Pine plot, since the group is well distributed in most of the plot, but in the first meters after the edge there are fewer individuals.

These findings are important because that means the late secondary and climax species can inhabit the whole area in the Agriculture plot, including the regions close to the edges. Besides the high density of individuals living close to the edge, it is noticed a large recruitment and low mortality of these species. This is important because this group of species usually do not adapt well to the edge areas and may tend to disappear or be extinct in forests with a large human disturbance (Pütz et al. 2011) since the environment favors shadow intolerant species (Vieira \& Hosokawa 1989). In the Pine plot, there are still some regions where this group is not so well distributed, but because of the presence of some individuals close to the edges, we can believe that the immediate effect of the edge creation is being minimized, since the effects of the edge are stronger in the first years (Harper et al. 2005; Laurance et al. 2011).

Considering the species more impacted by the edge distance in the Pine plot, we can notice that Cinnamomum amoenum presents many individuals living closer to the edge, and most of these were recruited in the studied period. However, there is only one individual in the first $10 \mathrm{~m}$ after the edge, and the largest concentration of this species is at 20-40 $\mathrm{m}$ of distance. This is an expected behavior since this species belongs to the early secondary group that is known for developing in small forest gaps, or more rarely, in the understory layer, in the shade (Leitão Filho 1993). The observed pattern is interesting because it shows a tendency of this species not well adapted to the edge itself, even having a negative correlation with the edge distance. A similar pattern was observed by Fontoura et al. (2006), who noticed the existence of this species after $50 \mathrm{~m}$ from the edge, and they characterized this species as shade tolerant.

Moquiniastrum polymorphum is highly concentrated in the first subplot of the Pine plot, so in direct contact with the exterior, an expected behavior for this species since is commonly found in edge areas (Pivello et al. 2006). Besides that, this species does not have a large density of individuals even in the edge region.

On the other hand, Clethra scabra presented the majority of its individuals in the first three subplots as a light demanding species, but it also showed trees in the plot interior. Clethra scabra did not present any region with a high density of individuals in the plot. Similarly, Pivello et al. (2006) observed Clethra scabra occurring predominantly in the edges, but also in interior areas, which may be a result of selective extractions of wood, since they may cause forest gaps and increased regeneration of pioneer species. This 
same process of selective logging occurred at the Experimental Station of São João do Triunfo, so the pioneer trees in the interior can be a result of this process.

Myrsine coriacea showed a similar trend to Moquiniastrum polymorphum with most of the individuals in the edge until approximately 30 meters from the forest edge. That happens because this species colonizes open areas that suffer disturbances in the Araucaria Rainforest (Scariot \& Reis 2010). At greater distances, only three recruitment trees of this species were found, and two of those are at less than $60 \mathrm{~m}$ of distance. An occurrence like this is probably a result of the presence of forest gaps. According to Sampaio (2011), these gaps can become a habitat for species that require higher availabilities of light, and that can affect the structural and floristic patterns of the forest. Also, it is interesting to notice that even close to the edge, this species is found in a specific area, i.e., this species is aggregated.

In the Agriculture plot, Eugenia uniflora showed a positive correlation with the increase in edge distance considering the living and recruitment trees, and this effect of the distance was also observed by the GAM model. This species has a higher concentration of individuals in interior areas, mostly in the west corner of the plot, and therefore can be negatively affected by the creation of edges. E. uniflora is classified as late secondary or climax, and it is characterized by living in high water saturation areas (Reitz et al. 1983), so probably will not occur in edge areas where there is a decrease in soil moisture (Murcia 1995). In our study, the presence of some trees of this species near the edge can be explained by their prior existence to the formation of the edge. As a species of slow growth, characteristic of climax species (Resende et al. 1999), it takes them longer to respond to the harmful effects originated with the formation of the edge.

The other species presented in the Kernel density maps are all concentrated close to the edges, even Nectandra lanceolata and Ocotea porosa, from the late secondary/climax ecological group. Nectandra lanceolata is highly concentrated in a small region of the plot in the east side of the two fist subplots. On the other hand, Ocotea porosa does not have any region with a high density of individuals, even it having more individuals in the first subplot distributed in almost all the plot. The results for these two species show as the possibility of shade tolerant species living close to the edges.
Styrax leprosus presented a high density of individuals in the first 30 meters from the edge as well as some in the interior. This species is classified as early secondary, and its presence in the edge reflects the abundancy of light there. According to Silva et al. (2012), Styrax leprosus is found in the middle layer of Araucaria forests, capões (Brazilian forest islands immersed on an herbaceous matrix) and grassland areas. A similar occurrence was observed for Ocotea puberula that also showed a large number of individuals close to the edge, and the few individuals in the interior are possible because of the presence of gaps in the canopy.

Considering the spatial distribution of species in Araucaria forest, usually these species present an aggregated distribution, as observed by Nascimento et al. (2001) and Silvestre et al. (2012), as well by Machado et al. (2012) for Araucaria angustifolia, Casearia decandra and Cedrela fissilis and for Rondon Neto et al. (2000) for Myrsine coriacea. This pattern means that in some cases, the concentrated distribution of some species in one region can be a result of their natural occurrence, as can be the case of E. uniflora, M. coriacea and N. lanceolata.

One interesting fact to note is the predominance of some species in the first three subplots, as happens for Myrsine coriacea, Cinnamomum amoenun, Clethra scabra, Moquiniastrum polymorphum and Styrax leprosus. This also is observed by the high density of pioneers and early individuals in the first subplots (up to 40 meters) in the Pine plot for the living and recruitment categories as well as for the living in the Agriculture plot. This result is similar to those reported by Rigueira et al. (2012), which indicates the predominance of pioneer and early secondary species in the first 30 meters from the edge. It is also interesting to observe that some studies have analyzed the Araucaria Forest expansion system and have found that this forest type expands its limits by promoting certain species, as pioneers with fast development over the edge limits (Carlucci et al. 2011). Because of the presence of a large number of species well adapted to this expansion process, the Araucaria forest can be considered less susceptible to changes in the environment such as the forest fragmentation (Orihuela et al. 2015).

The Kernel analysis of the late secondary/ climax ecological group showed that these groups are able to live and even regenerate close to the edges, especially in the Agriculture plot, which differ from the results observed by some studies. In 
general, our study suggests that there is a prevalence of pioneers and early secondary species close to the edges, while the late secondary/climax species are not concentered only in the interior. A similar finding was observed by Rigueira et al. (2012). Still, it is important to monitor the edge effect over the species since we can notice that some are more impacted by the edge, as E. uniflora. In some areas where the edge effect is prevalent, such as small forests, characteristic species of a specific forest type, mostly climax species, can be more vulnerable to extinction (Pütz et al. 2011) due to changes in the environment that impact their survival.

\section{Conclusion}

We conclude that in the Araucaria Rainforest some species are strongly affected by the presence of edge's areas. Some of these species are likely to live close to the edges, while others ae only presented in the interior areas, and because of that can be more negatively affected by the presence of edges.

The distribution of species considering the ecological groups also displayed relationship with the edge distance, being the pioneer/early secondary species mostly concentrated close to the edges, as expected. In addition, one of the most important findings of this study is that there is a good distribution of late secondary/climax species in both plots, what means that this group, usually considered most susceptible to the edge effects, can survive in the area even after the fragmentation.

\section{Complementary data}

This paper contains complementary data available at <http://doi.org/10.6084/ $\mathrm{m} 9$.figshare.4622221>. The materials available are: lists of individuals measured during the field inventory in Pine and Agriculture plots; Kernel density maps and GAM model of all analyzed species in Pine and Agriculture plots; and tables with Spearman's Correlation Coefficients and GAM results for individuals and ecological groups in Pine and Agriculture plots.

\section{Acknowledgement}

To CAPES to concession of scholarship and PELD Site 9 for data availability.

\section{References}

Baldissera R \& Ganade G (2005) Predação de sementes ao longo de uma borda de Floresta Ombrófila Mista e pastagem. Acta Botanica Brasilica 19: 161-165. Barreto TG (2015) Geoestatística aplicada à modelagem da dinâmica de crescimento e características químicas do solo de um fragmento florestal. Dissertação de Mestrado. Universidade Federal do Paraná, Curitiba. 187p.

Bianchi JS \& Kersten RA (2014) Edge effect on vascular epiphytes in a subtropical Atlantic Forest. Acta Botanica Brasilica 28: 120-126.

Carlucci MB, Teixeira FZ, Brum FT \& Duarte LDS (2011) Edge expansion of Araucaria forest over southern Brazilian grasslands relies on nurse plant effect. Community Ecology 12: 196-201.

Cochrane MA \& Laurance WF (2002) Fire as a largescale edge effect in Amazonian forests. Journal of Tropical Ecology 18: 311-325.

Dalla Lana M (2013) Dinâmica e prognose do crescimento em um fragmento de floresta ombrófila mista no sul do Paraná. Dissertação de Mestrado. Universidade Federal do Paraná, Curitiba. 187p.

De Cesaro A, Engel OA, Finger CAG \& Schneider PR (1994) Comparação dos métodos de amostragem de área fixa, relascopia, e de seis árvores, quanto a eficiência, no inventário florestal de um povoamento de Pinus sp. Ciência Florestal 4: 97-108.

Durigan ME (1999) Florística, dinâmica e análise protéica de uma Floresta Ombrófila Mista em São João do Triunfo - PR. Dissertação de Mestrado. Universidade Federal do Paraná, Curitiba. 125p.

Fahrig L (2003) Effects of habitat fragmentation on biodiversity. Annual Review of Ecology, Evolution, and Systematics 34: 487-515.

Felfili JM, Hilgbert LF, Franco AC, Sousa-Silva JC, Resende AV \& Nogueira MVP (1999) Comportamento de plântulas de Sclerolobium paniculatum Vog. var. rubiginosum (Tul.) Benth. sob diferentes níveis de sombreamento, em viveiro. Revista Brasileira de Botânica 22: 297-301.

Ferreira TS, Marcon AK, Salami B, Rech CCC, Mendes AR, Carvalho AF, Missio FF, Pscheidt F, Guidini AL, Dornelles RS, Silva AC \& Higuchi P (2016) Composição florístico-estrutural ao longo de um gradiente de borda em fragmento de floresta ombrófila mista alto-montana em Santa Catarina. Ciência Florestal 26: 123-134.

Fontoura SB, Ganade G \& Larocca J (2006) Changes in plant community diversity and composition across an edge between Araucaria Forest and pasture in South Brazil. Revista Brasileira de Botânica 29: 79-91.

Galindo-Leal C \& Câmara IG (2005) Atlantic Forest hotspot status: an overview. In: Galindo-Leal C \& Câmara IG (eds.) The Atlantic Forest of South America: biodiversity status, trends, and outlook. Center for Applied Biodiversity Science and Island Press, Washington. Pp. 3-11.

Geneletti D (2004) Using spatial indicators and value functions to asses ecosystem fragmentation caused by linear infrastructures. International Journal of 
Applied Earth Observation and Geoinformation 5: $1-15$.

Harper KA, MacDonald SE, Burton PJ, Chen J, Brosofske KD, Saunders SC, Euskirchen ES, Roberts D, Jaiteh MS \& Esseen P (2005) Edge influence on forest structure and composition in fragmented landscapes. Conservation Biology 19: 768-782.

Hauke J \& Kossowski T (2011) Comparison of values of Pearson's and Spearman's correlation coefficients on the same sets of data. Quaestiones Geographicae 30: 87-93.

Hentz AMK (2015) Mapeamento, fragmentação florestal e influência das áreas de borda para a comunidade arbórea no Alto Iguaçú - estado do Paraná. Dissertação de Mestrado. Universidade Federal do Paraná, Curitiba. 197p.

Lang S \& Blaschke T (2009) Análise da paisagem com SIG. Oficina de Textos, São Paulo. 424p.

Laurance WF \& Williamson GB (2001) Positive feedbacks among forest fragmentation, drought, and climate change in the Amazon. Conservation Biology 15: 1529-1535.

Laurance WF, Camargo JLC, Luizão RCC, Laurance SG, Pimm SL, Bruna EM, Stouffer PC, G Williamson B, Benítez-Malvido J, Vasconcelos HL, Van Houtan KS, Zartman CH, Boyle SA, Didham RK, Andrade A \& Lovejoy TH (2011) The fate of Amazonian forest fragments: a 32-year investigation. Biological Conservation 144: 56-67.

Laurance WF, Ferreira LV, Rankin-De-Merona JM \& Laurance SG (1998b) Effects of forest fragmentation on recruitment patterns in Amazonian tree communities. Conservation Biology 12: 460464.

Laurance WF, Goosem M \& Laurance SG (2009) Impacts of roads and linear clearings on tropical forests. Trends in Ecology \& Evolution 24: 659669.

Laurance WF, Ferreira LV, Meronal JMR \& Laurance SG (1998a) Rainforest fragmentation and the dynamics of Amazonian tree communities. Ecology 79: 2032-2040.

Laurance WF, Lovejoy TW, Vasconcelos HL, Bruna EM, Didham RK, Stouffer PC, Gascon C, Bierregaard RO, Laurance SG \& Sampaio E (2002) Ecosystem decay of amazonian forest fragments: a 22-year investigation. Conservation Biology 13: 605-618.

Leitão Filho HF (1993) Ecologia da mata atlântica em Cubatão. UNESP/ UNICAMP, São Paulo. 184p.

Machado SA, Santos AAP, Zamin NT \& Nascimento RGM (2012) Distribuição espacial de um fragmento de Floresta Ombrófila Mista Montana. Ciência Rural 42: 1013-1019.

Malchow E, Koehler AB \& Péllico Netto S (2006) Efeito de borda em um trecho da floresta Ombrófila Mista, em Fazenda Rio Grande, PR. Revista Acadêmica 4: $85-94$
Martins K, Santos JD, Gaiotto FA, Moreno MA \& Kageyama PY (2008) Estrutura genética populacional de Copaifera langsdorffii Desf. (Leguminosae - Caesalpinioideae) em fragmentos florestais no Pontal do Paranapanema, SP, Brasil. Revista Brasileira de Botânica 31: 61-69.

Matlack GR (1994) Vegetation dynamics of the forest edge: trends in space and sucessional time. Journal of Ecology 82: 113-123.

Medeiros JD, Savi M \& Brito BFA (2005) Seleção de áreas para criação de unidades de conservação na Floresta Ombrófila Mista. Biotemas 18: 33-50.

Murcia C (1995) Edge effects in fragmented forests: implications for conservation. Trees Reviews 10: 58-62.

Nascimento ART, Longhi SJ \& Doádi AB (2001) Estrutura e padrões de distribuição espacial de espécies arbóreas em uma amostra de Floresta Ombrófila Mista em Nova Prata, RS. Ciência Florestal 1: 105-119.

Orihuela RLL, Peres CA, Mendes G, Jarenkow JA \& Tabarelli M (2015) Markedly divergent tree assemblage responses to tropical forest loss and fragmentation across a strong seasonality gradient. PLoS ONE 10: 1-19.

Pirti A, Gumus K, Erkaya H \& Hosbas RG (2010) Evaluating repeatability of RTK GPS/GLONASS Near/Under forest environment. Croatian Journal of Forest Engineering 31: 23-33.

Pivello VR, Petenon D, Jesus FM, Meirelles ST, Vidall MM, Alonso RAS, Franco GADC \& Metzger JP (2006) Chuva de sementes em fragmentos de Floresta Atlântica (São Paulo, SP, Brasil), sob diferentes situações de conectividade, estrutura florestal e proximidade da borda. Acta Botânica Brasilica 20: 845-859.

Pütz S, Groenevelda J, Alves LF, Metzger JP \& Huth A (2011) Fragmentation drives tropical forest fragments to early successional states: a modelling study for Brazilian Atlantic forests. Ecological Modelling 222: 1986-1997.

R Core Team (2017) R: a language and environment for statistical computing. R Foundation for Statistical Computing, Vienna, Austria. Available at $<$ https:// www.R-project.org/>. Access on May 2017.

Reitz P, Klein RM \& Reis A (1983) Projeto Madeira do Rio Grande do Sul. Herbário Barbosa Rodrigues, Itajaí. 525p.

Resende AV, Neto AEF, Muniz JA, Curi N \& Faquin V (1999) Crescimento inicial de espécies florestais de diferentes grupos sucessionais em resposta a doses de fósforo. Pesquisa agropecuária brasileira 34: 2071-2081.

Ribeiro S \& Marques JCB (2005) Características da paisagem e sua relação com ocorrência de bugiosruivos (Alouatta guariba clamitans Cabrera, 1940; Primates, Atelidae) em fragmentos florestais no vale do Taquari, RS. Natureza e Conservação 3: 65-78. 
Rigueira DMG, Molinari ALM, Mariano DLS, Reis RM, Portugal AB, Santana NS \& Santos RA (2012) Influência da distância da borda e do adensamento foliar sobre a abundância de plantas pioneiras em um fragmento de floresta tropical submontana na Estação Ecológica de Wenceslau Guimarães (Bahia, Brasil). Acta Botanica Brasilica 26: 197-202.

Rodrigues PJFP \& Nascimento MT (2006) Fragmentação florestal: breves considerações teóricas sobre efeito de borda. Rodriguésia 57: 63-74.

Rondon Neto RM, Botelho SA, Fontes MAL, Davide AC \& Faria JMR (2000) Estrutura e composição florística da comunidade arbustivo-arbórea de uma clareira de origem antrópica, em uma floresta estacional semidecídua Montana, Lavras, MG, Brasil. Cerne 6: 79-94.

Sampaio RCN (2011) Efeito de borda em um fragmento de floresta estacional semidecidual no interior do estado de São Paulo. Dissertação de Mestrado. Universidade Estadual Paulista, Botucatu. 95p.

Santos JHS, Ferreira RLC, Silva JAA, Souza AL, Santos ES \& Meunier IMJ (2004) Distinção de grupos ecológicos de espécies florestais por meio de técnicas multivariadas. Revista Árvore 28: 387-396.

Savicky P (2014) pspearman: Spearman's rank correlation test. R package version 0.3-0. Available at $<$ https:// CRAN.R-project.org/package $=$ pspearman $>$. Access on May 2017.

Scariot A, Freitas SR, Neto EM, Nascimento MT, Oliveira LC, Sanaiotti T, Sevilha AC \& Villela DM (2003) Efeitos da fragmentação sobre a biodiversidade - vegetação e flora. In: Rambaldi DM \& Oliveira DAS (orgs.) Fragmentação de ecossistemas: causas, efeitos sobre a biodiversidade e recomendações de políticas públicas. $\mathrm{MMA} / \mathrm{SBF}$, Brasília. Pp. 104-123.
Scariot A, Souza-Silva JC \& Felfili JM (2005) Cerrado: ecologia, biodiversidade e conservação. Ministério do Meio Ambiente, Brasília. 439p.

Scariot EC \& Reis A (2010) Riqueza e estrutura florística de corredores ciliares em regeneração natural no planalto norte catarinense, sul do Brasil. Perspectiva 34: 53-65.

Schaaf LB, Filho AF, Galvão F \& Sanquetta CR (2006) Alteração na estrutura diamétrica de uma floresta ombrófila mista no período entre 1979 e 2000. Revista Árvore 30: 283-295.

Silva GS, Lima CS, Silva CSS \& Forneck ED (2012) Levantamento fitossociológico do estrato arbustivo regenerante em silvicultura de Araucaria angustifolia (Bertol.) Kuntze na floresta estacional de São Francisco de Paula, RS, Brasil. Revista de Ciências Ambientais 6: 113-127.

Silverman BW (1986) Density estimation for statistics and data analysis. Chapman and Hall, New York. $175 \mathrm{p}$.

Silvestre R, Koehler HS, Machado SA, Balbinot R \& Watzlawick LF (2012) Análise estrutural e distribuição espacial em remanescente de Floresta Ombrófila Mista, Guarapuava (PR). Ambiência 8: 259-274.

Vieira O \& Hosokawa RT (1989) Composição florística da vegetação da regeneração natural. 1 ano após diferentes níveis de exploração de uma floresta tropical úmida. Acta Amazonica 19: 401-413.

Wood SN (2011) Fast stable restricted maximum likelihood and marginal likelihood estimation of semiparametric generalized linear models. Journal of the Royal Statistical Society 73: 3-36.

Zuur AF, Ieno EN, Walker NJ, Saveliev AA \& Smith G (2009) Mixed effects models and extensions in ecology with R. Springer, New York. 574p. 